Пустовім Валерія, доктор філологічних наук, професор

\title{
ВІН ЗАВЖДИ ЗАЛИШАВСЯ ЛЮДИНОЮ
}

Моє перше знайомство з Анатолієм Васильовичем відбулося заочно. Як i для будь-кого з молодих аспірантів почути, а ще й побачити, а якщо повезе то й отримати наукову працю з дарчим підписом від професора, відомого ученого це була розкіш наукового життя. У скрутні 90-ті роки, коли вивчати літературу знаходилися люди, дійсно закохані в цю справу було не так багато. Матеріальна скрута, повна відсутність держзамовлення, безвихідь у друкуванні результатів дослідження - усе це було перешкодою на шляху до захисту дисертації. I наскільки було моє здивування, коли в інформаційному листі з Кривого Рога зазначалося про видання збірника матеріалів до початку роботи конференції. Це було солідне видання, 3 декількох томів, 3 гарною поліграфічною обкладинкою, мова йде про збірник, який сьогодні на слуху і $є$ в кожного в списку наукових праць «Література. Фольклор. Проблеми поетики». Саме тоді, перша стаття належала професору А. Козлову про виміри духовності в літературі. Простими словами, зрозумілими студентові й академікові Анатолій Васильович розмірковував про душу, дух та духовність персонажів творів художньої літератури.

3 того часу я завжди слідкувала на науковими розвідками професора А. Козлова, які часто друкувалися у фахових виданнях України. Очне знайомство відбулося набагато пізніше, в травні 2010 року під час проведення 
наукової конференції, присвяченої творчості Марка Кропивницького в м. Глухові Сумської обл. Серед знаних науковців, які доповідали на пленарному засіданні знову виокремився Анатолій Васильович, незважаючи на солідний вік, він зумів «пробудити» студентську аудиторію пізнавальною інформацією. Організатори конференції продумали багато цікавих екскурсій по ознайомленню 3 історичними пам'ятками останньої гетьманської резиденції. Саме тут, для мене по-новому, з людської, так би мовити, сторони відкрився Анатолій Васильович. Коли всі пішли дивитися склеп меценатів Терещенків, які багато зробили для України, для Глухова (вони вже тоді думали про екологічну ситуацію, тому й до сьогодні до Глухова не прокладено жодної залізничної колії), лише А. Козлов, один з великої групи гостей не пішов 3 нами, на моє запитання Чому? Сказав: «У мене своя точка зору на їхню діяльність, це моя людська позиція. Не піду!».

3 того часу ми стали часто спілкуватися телефоном, багато обговорювали дисертаційних робіт, обмінювалися відгуками й рецензіями. На прохання виступити рецензентом посібника для студентів Анатолій Васильович підійшов не формально, а критично прочитав й коректно висловив поради 3 покращення структури. Це було зроблено з батьківською любов’ю, не з метою приниження молодого ученого, а вберегти від невдачі.

У науковій роботі завжди дотримувався принципу - все складне треба викладати просто й доступно! Якщо радив, то робив це аргументовано, наводячи приклади з української та світової літератури, проводив паралелі, на ходу формулював тему, викладав план роботи над матеріалом.

Саме тоді Анатолій Васильович назвав мене Лєрхен! На свята, дні народження, визначні події мого життя - він завжди телефонував, називаючи тільки Лєрхен і бажання були не штамповані, а індивідуальні, я б сказала «неологізми по-Козлову».

У кожного з нас життя вирувало, не завжди вистачало сил і можливостей для спілкування, але якщо випадала нагода (Анатолій Васильович двічі бував на Луганщині) ми завжди знаходили час для приватної бесіди. 
Для мене Анатолій Козлов - науковець, учитель, але запам'ятається назавжди - справжнім чоловіком, ніколи не оминав можливості поцілувати жінці руку, допомогти одягти пальто, підтримати на слизькій дорозі, сказати комплімент чи просто підтримати добрим словом. А як він вправно вальсував! I неодмінне, Козловське - на кожну наукову конференцію - новий, стильний костюм!

I ще одне, особисте. Якими ніжними були стосунки 3 дружиною. Bci, хто знав цю наукову-подружню пару відзначали теплоту почуттів, яка була не на публіку, а йшла з глибини душі, звідти, де бачать лише двоє, які дивляться не один на одного, а в одну ціль.

Сьогодні, коли минув рік з дня смерті Анатолія Васильовича, його учні, друзі зібралися на наукову конференцію на честь вшанування його пам'яті. День конференції - 9 жовтня 2015 р. обрав він сам, сподіваючись ії провести. Але... Так повелося в Україні, що завжди дружина продовжує працю чоловіка, на високому рівні Світлана Іванівна провела конференцію, звичайно ж видала матеріали конференції, які вже друкувалися в новому форматі «Літератури світу: поетика, ментальність і духовність». Під час пленарного лунали улюблені пісні, вірші, спогади, а 3 телеекрану дивися на нас усміхнений Анатолій Васильович.

Сєвєродонецьк, жовтень 2015 р. 